\title{
NATIONAL COURT INTERVENTION IN ARBITRATION AS AN INVESTMENT TREATY CLAIM
}

\author{
I. INTRODUCTION
}

International commercial arbitration has long been a popular method for resolving cross-border business disputes. The opportunity for parties to choose their adjudicators and the dispute resolution procedure, the scope for privacy and the greater capacity for enforcement of awards compared to court judgments are all important reasons that parties prefer international arbitration over litigation. Reinforcing this trend in favour of international commercial arbitration has been a general consensus among national courts and legislatures that support, rather than interference, should be provided to the arbitral process. Such a philosophy is apparent, for example, in the requirements in the widely adopted New York Convention for States to recognize and enforce both foreign arbitration agreements and awards, and in international instruments such as the 1985 UNCITRAL Model Law on International Commercial Arbitration, which authorize national courts to assist, rather than intervene, in the conduct of arbitrations within their borders. Moreover, international commercial arbitration has proven to be sufficiently flexible as a dispute resolution method to be used both in disputes between private parties, and between private and State entities.

In the case of disputes between private corporations and State enterprises, international arbitration under institutional rules such as the ICC or ad hoc arbitration under the UNCITRAL Rules have commonly been employed. More recently, a parallel dispute resolution system has emerged known as 'investor-state arbitration'. Unlike international commercial arbitration, which derives its existence from a contractual stipulation to arbitration, investor-state arbitration is created by treaty between States typically conferring rights of arbitration on 'investors' against 'host states'. Such arbitral mechanisms are often found in bilateral investment treaties (BITs) or free trade agreements such as the NAFTA.

The object of this article will be to examine the role of investor-state arbitration in adjudicating disputes concerning the conduct of States in relation to international commercial arbitration. It will be suggested, by reference to a recent ICSID tribunal decision in Saipem v Bangladesh, that investors now have scope for review of State action - both by the executive and the judiciary - in respect of arbitrations. Such a pathway has the potential to enhance the arbitral process by providing redress for salient abuses by States.

\section{STATE ARBITRATION AGREEMENTS}

\section{A. State Repudiation of Arbitration}

Investor-state arbitration grew out of the traditional public international law doctrine of diplomatic protection, whereby a State could espouse a claim on behalf of one of its nationals against another State where the national had suffered an injury at the hands of that State. Pertinently for this article, a number of diplomatic protection cases involved situations of government 'negation' of arbitration, such as where a State repudiated an 
arbitration agreement entered into with a foreign national. ${ }^{1}$ Typically, such repudiation was manifested by refusing to participate in the arbitral process and/or enacting laws to nullify the agreement. In such cases it was generally agreed, both in judicial/ arbitral practice and academic commentary, that the foreign national had suffered a 'denial of justice' which enlivened the right of its State of nationality to exercise diplomatic protection on the individual's behalf. ${ }^{2}$ Alternatively, where the State's conduct did not reach the level of a denial of justice but still amounted to a breach of the rules of public international law, for example for violation of a treaty obligation, then the injured State would have a direct claim against the offending State. ${ }^{3}$ Yet both the 'direct' State $\mathrm{v}$ State action and diplomatic protection routes were frequently not invoked in practice because the claimant State chose not to do so for often unrelated political reasons, leaving the injured individual without redress. ${ }^{4}$ Consequently, State interference in arbitration to which it was a party was a problem which often went unremedied.

How have injured private parties responded to this predicament? One approach has been to persuade the designated arbitral tribunal, under the original arbitration agreement, to continue with the arbitration despite the government intervention, and deliver an award which could then be enforced in a 'friendly' country. A number of brave tribunals have followed this course, sometimes relocating the arbitration hearings to a neutral jurisdiction to avoid harassment and intimidation by the State party in the seat of arbitration. In the famous Himpurna ${ }^{5}$ and Salini ${ }^{6}$ cases, arbitral tribunals followed this path, justifying their actions on the basis that the power of an arbitral tribunal is derived from the parties' agreement and international law principles rather than the domestic law of the seat. ${ }^{7}$ In this way the tribunal can use the rules in the agreement to insulate itself from intervention by the courts of the seat. Such an approach is reminiscent of the 'delocalized' approach to arbitration, which has not been generally accepted in common law countries ${ }^{8}$ although has some recognition in the laws of European countries. ${ }^{9}$ While, accordingly, common law commentators have been guarded ${ }^{10}$ in their response

1 See, for a full discussion, S Schwebel, International Arbitration: Three Salient Problems (Cambridge, Grotius Publications, 1987) 61.

3 J Paulsson, Denial of Justice in International Law (CUP, Cambridge, 2005) 69.

4 For two recent cases where courts were unwilling to review decisions by governments on the exercise of the right to diplomatic protection see Khadrv Prime Minister of Canada 2010 SCC 3 para 44 (Sup Ct Can) and Kaunda v President of the Republic of South Africa (2004) 136 ILR 152 para 77.

5 Himpurna $v$ Indonesia interim award of 26 September 1999, final award of 16 October 1999, in (2000) XXV Yearbook of Commercial Arbitration 109.

6 Salini Costruttori SpA v The Federal Democratic Republic of Ethiopia ICC Arbitration No. 10623/AER/ACS Award Regarding the Suspension of the Proceedings and Jurisdiction, 7 December 2001 extracted in E Gaillard (ed), Anti-suit Injunctions in International Arbitration (Juris Publishing Inc, 2005) Annex 4, 227.

7 Salini, ibid paras 128, 134, 177-178; Himpurna paras 113-114.

8 For England see Bank Mellat v Helliniki Techniki [1983] 3 WLR 783, 789 (CA per Kerr LJ); for the United States see Scherk v Alberto Culver 417 US 506, 519 (1974) (US Sup Ct) and for Australia see American Diagnostica v Gradipore (1998) 44 NSWLR 312.

9 See eg Belgium: Code Judicaire art 1717; France: Code Of Civil Procedure art 1494.

10 See eg A Redfern and M Hunter, Law and Practice of International Commercial Arbitration (Sweet and Maxwell, London, 2004) 412. 
to the approach taken in the Salini and Himpurna cases, civil law observers have been supportive. ${ }^{11}$

Such arbitral independence from the laws and courts of the seat has occasionally been mirrored in decisions by courts in other States who have enforced arbitral awards under article VII of the New York Convention-despite the award having been set aside by the courts at the seat of arbitration. ${ }^{12}$ Yet both such approaches are almost as imperfect and unpredictable for investors as diplomatic protection, given the sensitivities involved in arbitrators and foreign courts simultaneously passing judgment on the conduct of other States and evading their laws. There is also the practical problem that the defendant State must have assets in another jurisdiction for the private claimant to recover, since it is highly unlikely that the State court which interfered with the arbitration would enforce an arbitral award.

Consequently, a new dispute resolution vehicle was required where private investors could obtain direct redress from a neutral forum for negation by States of their obligation to arbitrate. One such vehicle is investor-state arbitration and another, in the European context, is review by the European Court of Human Rights (ECtHR), an avenue which will not be explored further in this paper. ${ }^{13}$

In the case of investor-state arbitration, there are arguably a number of grounds available to challenge a State's conduct in respect of an arbitration to which it is a party. Most BITs contain a provision requiring a State to provide 'fair and equitable treatment' to an investor ${ }^{14}$ as well as a duty not to expropriate the investment. ${ }^{15}$ Still other BITs contain more specific undertakings to 'provide effective means of asserting claims and enforcing rights with respect to investment" ${ }^{16}$ or 'to permit investors ... to select means of their choice to settle disputes including arbitration' and 'to ensure the recognition and enforcement of any ... award'. ${ }^{17}$

Before considering the meaning and scope of the above provisions, some discussion should be made of the types of State conduct in relation to arbitration which could be the subject of challenge by investors. One type of case is where the State seeks to frustrate and undermine the arbitration process by refusing to appoint an arbitrator where the agreement requires the State to make an appointment. ${ }^{18}$ An analogous situation is where the State seeks to restrain the investor, by court injunction, from

11 See eg M de Boisseson, 'Anti-Suit Injunctions Issued by National Courts at the Seat of the Arbitration or Elsewhere' in Gaillard (n 6) 69 and Paulsson (n 3) 152.

12 In the Matter of the Arbitration of Certain Controversies between Chromalloy Aeroservices and Egypt 939 F Supp 907 (DDC 1996). See also Omnium de Traitement et de Valorisation (OTV)(France) v Hilmarton (UK) (1997) XXII Yearbook of Commercial Arbitration 696 (Decision of the French Cour de Cassation 10 June 1997).

13 In Stran Greek Refineries and Stratis Andreadis v Greece [1994] 19 ECHRR 368 the ECtHR held that Greece had violated art 6(1) of the European Convention on Human Rights, providing for a right of access to a tribunal, where it passed a law which invalidated certain arbitral awards ahead of a hearing before the Greek courts in which the State had sought to have an award set aside. Such a law amounted to a repudiation by Greece of its obligation to arbitrate.

14 See eg US-Argentina BIT art II(2)(a). 15 ibid art IV(1).

16 See eg US-Ecuador BIT art II(7). In Chevron Corporation (USA) v Ecuador, Partial Award on the Merits 30 March 2010 para 244, this provision was said to provide 'a distinct and potentially less demanding test' than that required to show a denial of justice under customary international law.

17 See eg Australia-Philippines BIT art 14(b) and (c).

18 See eg National Iranian Oil Company (NIOC) v Israel (French Cour de Cassation 1 February 2005) referred to in Paulsson (n 3) 155-157. 
pursuing arbitration or perhaps more dramatically, where it seeks to prohibit the arbitral tribunal itself from proceeding with the reference. ${ }^{19}$ Typically in these situations the State will rely on its own legislation or constitution to assert that the arbitration agreement is invalid or that such law renders the State incapable of being a party to the agreement. ${ }^{20}$ Legislation which is specifically enacted to target the contracting investor is an even more extreme case. ${ }^{21}$

The key element in these situations is that the State has repudiated its promise to the investor to arbitrate disputes between them. Such conduct would amount to a 'denial of justice' in international law because the State is preventing access by the investor to an arbitral process to which the State has agreed. ${ }^{22}$ Such conduct is also arguably in breach of accepted principles of international arbitration law, specifically article II(1) of the New York Convention, which requires contracting States to recognize arbitration agreements in international contracts. ${ }^{23}$ As will be argued below, such action also constitutes a breach of provisions in investment agreements. Repudiation would not however be shown where the State party merely refused to contribute to an advance payment of the costs of the arbitration. ${ }^{24}$

\section{B. Responsibility for Acts of State Courts}

A further important point needs to be noted. While the above conduct involves the State as a party to an arbitration agreement seeking relief or refusing to participate in the process in circumstances inconsistent with its duty to arbitrate, there is another State entity involved: the courts. Where a State's court acts in collusion or conspiracy with its executive to obstruct an investor's pursuit of arbitration, then it too has committed a denial of justice and a breach of internationally accepted principles of arbitration law, for which its State is responsible. ${ }^{25}$ Some tribunals and commentators have suggested an even wider basis for 'judicial' denial of justice in relation to arbitration. They argue that, even in the absence of evidence of collusion with the executive, the mere granting of relief by a State's court at the request of its executive, which has the

19 The Salini and Himpurna cases above both involved such conduct.

20 Among many examples see Benteler v Belgium (1985) 8 European Commercial Cases 101 and Framatame SA v Atomic Energy Organisation of Iran (1982) (ICC Case No. 3896) referred to in Salini v Ethiopia at para 161.

${ }^{21}$ Schwebel (1987) (n 1) 63-64 citing the example of the seizure of the property of the AngloIranian Oil Company by Iran in 1951 .

${ }^{22}$ Benteler v Belgium (1985) 8 European Commercial Cases 101; Schwebel (1987) (n 1) 6066 and 'Anti-Suit Injunctions in International Arbitration: An Overview' in Gaillard (n 6) 12; Paulsson (n 3) 149-157 and FA Mann, 'State Contracts and International Arbitration' (1967) 62 British Yearbook of International Law 26-29. While some writers on investment law refer to denial of justice as being exclusively judicial in nature (eg C McLachlan, L Shore and M Weinger, International Investment Arbitration (OUP, Oxford, 2007) 226), it is clear that the concept also embraces conduct by a state's executive in relation to an arbitration on the basis that 'justice is universally denied' in such a situation; see Schwebel (1987) (n 1) 65.

23 If, however, the arbitration agreement is domestic in nature, that is, between a State and a local corporation and governed by local arbitration law, State frustration of the process is less likely to be a breach of universal principles of international arbitration law: see Duke Energy Electroquil Partners v Ecuador ICSID Case No. ARB/04/10 Award of 18 August 2008 para 396.

${ }^{24}$ Waste Management Inc $v$ United Mexican States Case No. ARB(AF)/00/3 Award of 30 April 2004 para 123.

25 Saipem SpA v Bangladesh ICSID Case No. ARB/05/7 Award of 30 June 2009 para 147. 
effect of nullifying the arbitration agreement, amounts to a denial of justice and a breach of universal international arbitration law principles by the court. ${ }^{26}$ The antiarbitration injunction is often cited as the seminal example of such relief.

While courts may be independent of the executive in many legal systems, an appearance of influence or preference may still be created when a State invokes its own courts to paralyse an arbitration proceeding and the court grants such relief. In effect the court may be seen as an 'instrument' of the State's strategy of repudiation. In a very recent ICSID award, discussed in detail below, ${ }^{27}$ a tribunal goes close to accepting this proposition. It did require, however, that for a State court to have committed a denial of justice in this situation, there must be some further misconduct by the court, such as uncritically accepting the executive's allegations. ${ }^{28}$

It is suggested that the tribunal's more cautious approach to this issue must be correct given the instances in international instruments where court involvement in arbitration proceedings is permissible. If a State court were to be held to have denied justice in every case where it granted relief in respect of an arbitration simply because the applicant happened to be its executive, then arguably the rights granted under those instruments would be compromised. ${ }^{29}$

For example, international instruments such as the New York Convention, the UNCITRAL Model Law and national arbitration statutes all provide some scope for judicial intervention in the arbitral process. Under article II(3) of the New York Convention, a court may legitimately refuse to stay a court proceeding brought in breach of an arbitration agreement where the agreement is null and void, inoperative or incapable of being performed. Equally, under article V of the Convention, a foreign award may be refused enforcement where any of a number of grounds is present (eg because enforcement of the award would violate the public policy of the forum ${ }^{30}$ or because the award pronounces on matters beyond the scope of the parties' submission to arbitration). ${ }^{31}$ Similarly, under the UNCITRAL Model Law, a court at the seat of arbitration may refuse to appoint an arbitrator where there is no valid arbitration agreement between the parties, ${ }^{32}$ or may remove an arbitrator where there are justifiable doubts as to his or her independence or impartiality. ${ }^{33}$ Also, an award may be set aside by a court under the Model Law where any of the grounds derived from article $\mathrm{V}$ of the New York Convention exist. ${ }^{34}$

These examples are provided to show that a significant 'margin of appreciation' and discretion is granted to national courts over arbitrations by principles of international arbitration law, particularly in the case of the supervisory courts at the seat of arbitration. Instinctively therefore, it would seem difficult for a party to elevate a court decision on any of the above matters into a 'denial of justice' or other investment treaty breach. Possible exceptions to this rule would be where the decision was so outrageous that no reasonable court could have arrived at it, or there was a fundamental breach of

26 Schwebel (2005) (n 6) 13; Himpurna para 187.

27 See Section IV.

28 Saipem v Bangladesh para 157.

29 Moreover, the global trend toward judicial 'assistance' rather than interference in arbitration should hopefully reduce the number of cases where the conduct of state courts is called into question.

30 Art V(2)(a).

31 Art V(1)(c).

32 UNCITRAL Model Law art 11; Pacific International $v$ Tsinlien Metals and Minerals Co (HK) Ltd [1993] 2 HKLR $249 . \quad{ }^{33}$ Art 12(2). 34 Art 34. 
due process, ${ }^{35}$ such as where the court refused to hear a party or made or allowed discriminatory remarks to be made about them. ${ }^{36}$

The above view is supported by the analysis of Paulsson, where he draws a distinction between a serious breach of 'general principles of international law' which reaches the level of a denial of justice and a 'mere' infringement of a treaty which would only create liability as between States themselves in international law rather than to an investor under an investment protection treaty. ${ }^{37}$ The idea here is that while a national court's decision interpreting the New York Convention may arguably be wrong as a matter of law, such an error does not amount to a denial of justice. The decisions of ICSID tribunals in which errors by State courts on the merits have not been found to amount to denials of justice are consistent with this view. ${ }^{38}$

All of these factors may explain the lack of investor-state jurisprudence on national court conduct in relation to arbitrations. There may also be another reason. Suppose, for example, that an investor were to argue before an ICSID tribunal that a national court's decision to refuse enforcement of a foreign award violated a provision in a BIT on fair and equitable treatment. A problem confronting the ICSID tribunal here may be that if it were to find a breach of the BIT, this could have the effect of undermining or even contravening the New York Convention if, for example, the court's decision concerned an issue (for example public policy) where national courts are granted considerable discretion. In practice, therefore, it may be very difficult to challenge national court decisions on arbitration matters where accepted international arbitration principles grant a wide field of operation to the courts.

Consequently, a State court cannot be found to have denied justice to an investor merely because it has granted relief at the request of its executive in respect of an arbitration agreement; something more is required, in the form of clear evidence of collusion, a dereliction of duty by the court or the ordering of a remedy which seriously deviates from accepted international standards. An anti-arbitration injunction is arguably such a remedy.

In this regard, it was mentioned above that such injunctions infringe both the terms and the spirit of the New York Convention, because they constitute a failure by a State (as a party to the agreement) to recognize an arbitration agreement in international commerce. The same argument can be made in relation to the State court which grants the order. Indeed, the issuing of such an injunction by a court also violates the concept of 'competence/competence' whereby the arbitral tribunal is judge of its own jurisdiction and the legality of the arbitral agreement in advance of any award issued by the tribunal. ${ }^{39}$ The principle of competence/competence is found in all major national arbitration laws ${ }^{40}$ as well as article 16 of the UNCITRAL Model Law.

To summarize, therefore, there would seem to be a compelling argument that a State's repudiation of an arbitration agreement can amount to a denial of justice and a breach of general principles of international arbitration law. Where a State's courts

35 Paulsson (n 3) 204-205.

36 Such as in the Loewen case; see Loewen Group Inc v United States of America ICSID Case No. ARB(AF)/98/3 Final Award 26 June 2003 para 135.

37 Paulsson (n 3) 69, 84-86.

38 Mondev International Ltd $v$ United States of America 6 ICSID Rep 181 (2002); Waste Management Inc v United Mexican States (n 24).

39 Schwebel (2005) (n 6) 14-15, F Bachand, 'The UNCITRAL Model Law's take on Anti-Suit Injunctions' in Gaillard (n 6) 112.

40 See eg Arbitration Act 1996 (UK) s 30. 
have colluded in such behaviour or engaged in serious misconduct in respect of the arbitration, then they too can be said to have denied justice to the losing party. The scope for such conduct to be remedied under specific provisions of investor-state treaties will now be considered.

\section{Investment Treaty Breaches}

As discussed above, there are a number of provisions of BITS which would arguably embrace State conduct in repudiating or unfairly interfering with an arbitration agreement. The first such ground, 'fair and equitable treatment', has been interpreted by a number of investor-state tribunals to encompass the concept of denial of justice referred to above. ${ }^{41}$ A denial of justice claim does, however, have a complication from an investor's perspective. That is, at least where the claim of denial of justice is made in relation to conduct of the State's courts, the investor must exhaust local remedies in the defendant State ${ }^{42}$ although a number of commentators have criticized this requirement. ${ }^{43}$ Where, however, it is the conduct of the executive which is being challenged, arguably the rule does not apply. This conclusion flows from the fact that where decisions of administrative authorities have been challenged for violation of the fair and equitable treatment obligation, the local remedies rule has not been imposed. ${ }^{44}$

Interestingly though, in a recent decision of an ICSID tribunal in Duke Energy Electroquil Partners $v$ Ecuador, ${ }^{45}$ the tribunal did require the investor to exhaust local remedies in a claim against the State (executive) for repudiation of an arbitration agreement. What was particularly unsatisfactory about the tribunal's decision was that the investor had specifically argued that the local remedies rule did not apply in the case of executive repudiation, ${ }^{46}$ but the tribunal made no response to this argument and simply assumed without discussion that the rule applied. The ICSID tribunal then went on to find that the investor had failed to exhaust local remedies by not challenging the original arbitral award in the State's courts, rejecting the investor's further argument that such remedy was futile given the improbability that the State's courts would set aside the arbitral award.

Hopefully the decision in Electroquil requiring the exhaustion of local remedies will not be followed in later cases of State repudiation, as it will impose a further and unreasonable burden on investors in seeking redress in investor-state arbitration. Moreover, it may be argued that exhaustion of local remedies in the legal system of the host State is beside the point in cases of executive repudiation of arbitration since arbitration is the sole remedy which was chosen by the parties and so "the sole remedy

41 Waste Management Inc $v$ United Mexican States Case No. ARB(AF)/00/3 Award of 30 April 2004 para 98; Jan de Nul NV v Arab Republic of Egypt ICSID Case No. ARB/04/13 Award of 6 November 2008 para 188.

${ }^{42}$ Loewen Group n 36 above; Jan de Nul NV v Arab Republic of Egypt para 258; Chevron v Egypt (n 16) para 321; Paulsson (n 3) 130.

${ }_{43}$ McLachlan, Shore and Weiniger (n 22) 231-233; D Wallace, 'Fair and Equitable Treatment and Denial of Justice: Loewen $v$ US and Chattin $v$ Mexico' in T Weiler (ed), International Investment Law and Arbitration (Cameron May 2005) 669, 699.

44 A Bjorklund, 'Reconciling State Sovereignty and Investor Protection in Denial of Justice Claims’ (2005) 45 Virginia Journal of International Law 809, 858.

${ }^{45}$ See (n 23).

46 ibid 399. 
which is to be exhausted'. ${ }^{47}$ There are, therefore, no equivalent local remedies to exhaust. $^{48}$

The second BIT obligation referred to above-expropriation-would also likely be breached in the case of repudiation of or unfair interference in an arbitration agreement. In such a case it is arguable that the State has seized the investor's contractual right to arbitrate disputes. ${ }^{49}$ In a recent decision, ${ }^{50}$ an ICSID tribunal held in effect that an investor's right to arbitrate a dispute was property which could be the subject of an expropriation claim against a State, and that expropriation could arise from repudiatory conduct by the State or gross interference in the arbitral proceedings by the State's courts. The same tribunal also found that there was no requirement to exhaust local remedies where expropriation is claimed. ${ }^{51}$ The clear discrepancy with denial of justice cases on this point may encourage investors to rely on expropriation instead in cases of State repudiation of arbitration agreements, both where the State actor is involved is the executive or the judiciary.

The third BIT obligation referred to above-that the State must 'permit investors ... to select means of their choice to settle disputes including arbitration' would again arguably be infringed by State conduct in relation to an arbitration agreement. In the Electroquil case the ICSID tribunal interpreted a similar provision to be the equivalent of a prohibition on denial of justice. Such a provision would therefore be breached according to the tribunal if a State exercised pressure or exerted undue influence on an arbitral tribunal with respect to its jurisdiction. ${ }^{52}$ The equation by the tribunal in Electroquil with denial of justice, however, did lead to the consequence that the local remedies rule applied, which should be borne in mind by an investor seeking to challenge conduct by a State's executive or its judiciary under this ground.

\section{Anti-ICSID Injunctions}

While the focus of this article is using investor-state arbitration to review State interference in international commercial arbitration proceedings, an interesting question arises if a State seeks to frustrate an investor-state arbitration proceeding. For example, what would the legal position be and what remedies would be available to an investor in the event that the State obtained an injunction from its courts restraining the investor from proceeding with an ICSID arbitration against the State? This situation arose most famously in the $S G S v$ Pakistan case. ${ }^{53}$ There, the State obtained an injunction enjoining an ICSID arbitration yet the tribunal proceeded with the matter in defiance of the court order. ${ }^{54}$ The tribunal asserted that it had a duty to protect the right of access to international adjudication 'for the proper operation of both the BIT and the ICSID Convention'. ${ }^{55}$ In other words, the State's conduct in seeking such relief was a denial of justice, a conclusion which is supported by commentators. ${ }^{56}$

\footnotetext{
${ }^{47}$ Schwebel (1987) (n 1) 117.

${ }^{49}$ Schwebel (2005) (n 6) 13.

51 ibid para 181 .

48 ibid 121.

50 Saipem SPA v Bangladesh para 128.

Duke Energy Electroquil Partners v Ecuador para 394.

Decision of 3 July 2002 reported at (2003) 19 Arbitration International 182.

54 Procedural Order No. 2 of 16 October 2002 reported at (2003) 18 ICSID Rev-Foreign Investment Law Journal 293.

${ }^{56}$ Schwebel (2005) (n 6) 12.
} 
An 'anti-ICSID injunction' would arguably place the State in clear breach of its obligations under article 26 of the ICSID Convention, which provides that the 'consent of the parties to arbitration under this Convention shall ... be deemed consent to such arbitration to the exclusion of any other remedy'. The suggestion made above that State repudiation of arbitration breaches article II(1) of the New York Convention would also be applicable here. So it seems the best option for the investor in such a situation is to request that the investor-state tribunal proceed with the arbitration despite the injunction in the same way as occurred in the Salini and Himpurnia cases. Otherwise, the only other method of redress would be for the investor's State to exercise diplomatic protection on its behalf. $^{57}$

Very recently, the State of Ecuador sought an injunction from a US court restraining Chevron from proceeding to investor-state arbitration. The request was refused, with the court noting 'the strong policy [in US law] in favour of arbitration and the lack of express authorization to stay arbitration under the New York Convention'. ${ }^{58}$

\section{NON-STATE ARBITRATION AGREEMENTS}

The next part of the article concerns the situation where the arbitration agreement does not include the State as a party and so there can be no suggestion of State repudiation of arbitration or conscious involvement by the courts in such a strategy. Instead the issue is that a State's courts, in the context of a dispute between wholly private parties, have so interfered with or compromised an arbitration agreement that the courts arguably have committed a denial of justice for which the State is responsible.

The analysis is however different from the case of State arbitration agreements considered above because there the State's courts, to found a breach of investment treaty law, must have been deliberately acting in aid of the State's intention to frustrate the arbitral process or there must at least be an inference of collusion derived from misconduct or delinquency by the court. By contrast, where the State's courts are adjudicating a dispute between private parties (or between a private party and another State) the possibility of collusion between judiciary and executive is remote. Hence, in this situation, it is suggested that it will be difficult to establish a breach of investment treaty standards unless there is present a very high level of misconduct or deviation from internationally accepted principles by the court.

The international instruments referred to above, such as the New York Convention and the Model Law, make it clear that State courts retain discretionary powers to intervene in the arbitral process, although the trend is toward limiting court involvement. Consequently, as was argued above, to establish a denial of justice or other investment treaty breach by a State court in respect of an arbitration will require a serious breach of due process, an outrageous decision or the granting of relief which clearly deviates from accepted principles of international law. Once again, the antiarbitration injunction would be an obvious candidate, but to sustain this argument it is necessary to look at national court practice on the issuing of such injunctions in nonstate arbitrations.

$57 \mathrm{C}$ Greenwood, 'Anti-Suit Injunctions in International Arbitration: A Public International Lawyer's Perspective' in Gaillard (n 6) 151.

58 Republic of Ecuador v Chevron Corporation 2011 US App LEXIS 5351 (2nd Cir CA 17 March 2011)*15. 


\section{A. Non-state Anti-arbitration Injunctions}

Under the New York Convention and the Model Law, there is no reference to antiarbitration injunctions, and in the case of the Convention, it was noted above that where a State is granted an anti-arbitration injunction by its own courts then the court has infringed article II(1) and (3), which require a court to recognize and enforce arbitration agreements unless invalid or inoperative.

Conceivably a similar, although possibly less powerful, argument could be made where a court grants an anti-arbitration injunction to a private entity. Although in such a case there is no suggestion of State repudiation of an arbitration agreement or conspiracy by the State's courts the courts are still being used as a vehicle to frustrate the process with the result that the losing party is denied justice. National practice in 'nonstate' anti-arbitration injunctions is moving in this direction, especially where the injunction is sought to enjoin arbitral proceedings taking place outside the seat. For example, the absence of reference to anti-suit injunctions in the Model Law, when coupled with the strict admonition in article 5 that 'no court shall intervene except as provided in this Law', supports the view that anti-arbitration injunctions are prohibited under the Model Law. ${ }^{59}$

English courts have taken a less categorical approach to non-state anti-arbitration injunctions. Before the enactment of the Arbitration Act 1996 it was acknowledged that jurisdiction existed to grant such relief but that it should be exercised cautiously. ${ }^{60}$ More recently, English courts have stated that they are generally unwilling to grant anti-arbitration injunctions although they will do so in exceptional circumstances.

In the case of an injunction to enjoin an arbitral tribunal outside England, the Court of Appeal has cast doubt on whether a jurisdiction to grant such orders even exists, given that the seat is foreign and English courts have no supervisory jurisdiction over the arbitration and that such relief would infringe the principles of the New York Convention. ${ }^{61}$ The same approach would also likely be taken where the 'target' of the injunction was the claimant rather than the arbitral tribunal itself.

In the context of applications to enjoin arbitrations taking place in England, English courts have tentatively accepted that a jurisdiction exists to order such relief but that it should be rarely exercised. In Elektrim $S A v$ Vivendi Universal $S A^{62}$ an injunction to restrain a party from pursuing LCIA arbitration proceedings in London was refused whereas in two other cases injunctions were exceptionally granted. In Albon v Naza Motor Trading $S d n B h d,{ }^{63}$ it was arguable that the arbitration agreement was a forgery and, in any event, the parties had agreed to submit this question to resolution by the English courts and so 'waived' the right to arbitrate the matter. Similarly in Kazakhstan $v$ Istil Group $\operatorname{Inc}^{64}$ an injunction was granted to restrain an arbitration after a court had earlier found that there was no arbitration agreement; the parties were therefore estopped from re-opening the issue.

In both these cases, therefore, there was in fact no arbitration agreement capable of being enforced. Absent this exceptional situation, however, or possibly where the

59 Bachand (n 6) 91.

60 The 'Oriana' and the 'Tunisie' [1966] 1 Lloyd's Rep 477 (injunction refused due to applicant's delay in seeking relief).

61 Weissfisch v Julius [2006] EWCA Civ 218 para 33.

62 [2007] EWHC 5571 (Comm).

64 [2007] EWHC 2729 (Comm).

${ }^{63}$ [2007] EWCA Civ 1124. 
arbitration agreement is plainly invalid, a non-state anti-arbitration injunction is in breach of general principles of international arbitration law ${ }^{65}$ and arguably gives rise to an actionable breach under investment treaties.

North American practice on anti-arbitration injunctions is consistent with the English position. While some United States courts have enjoined arbitration proceedings with $U S$ seats ${ }^{66}$ in a recent decision an injunction to restrain arbitration in Paris was refused, ${ }^{67}$ with the Court stating that anti-arbitration injunctions were inconsistent with purposes of the New York Convention. ${ }^{68}$ Similarly, in Canada, while courts in some earlier decisions supported the grant of anti-arbitration injunctions ${ }^{69}$ in more recent cases there has been a marked reluctance to order such relief. ${ }^{70}$

Hence, there appears to be a growing international consensus that non-state antiarbitration injunctions are a violation of international law principles as they violate the right of parties to have access to their chosen method of dispute resolution: arbitration. Given this increased recognition of the 'denial of justice' inherent in such orders it will be interesting to see if they form the basis of future actions before investor-state tribunals.

\section{THE SAIPEM DECISION}

The very recent award of an ICSID tribunal in Saipem $v$ Bangladesh is instructive in light of the above discussion. That case involved a dispute between an Italian company (Saipem) and a Bangladeshi State-owned company (Petrobangla) which was referred to ICC arbitration in Dhaka, Bangladesh in accordance with the parties' contract. During the course of the arbitration Petrobangla made a number of procedural objections which were dismissed by the arbitral tribunal. Before an award was given, Petrobangla applied to the Bangladeshi courts for revocation of the ICC tribunal's authority which was granted on the ground that the tribunal had misconducted the proceedings. The local court also granted an injunction enjoining Saipem from proceeding with the ICC arbitration. The tribunal ignored the orders of the Dhaka Court, proceeded with the arbitration, and gave an award in favour of Saipem. Petrobangla then successfully applied to the Supreme Court of Bangladesh to have the award set aside with the Court finding that the award was a 'nullity' as a result of the earlier decision by the lower court to revoke the authority of the tribunal. Saipem then commenced an ICSID arbitration arising from the provisions of the Italy-Bangladesh BIT, arguing that the Bangladeshi courts had 'expropriated' its investment.

The Saipem case involved an arbitration agreement between an investor and a State-owned company and so falls within the first part of this article as a 'State arbitration agreement'. As argued above, to establish a breach of investment treaty by a

65 J Lew, 'Anti-Suit Injunctions Issued by National Courts to Prevent Arbitral Proceedings' in Gaillard (n 6) 32.

${ }^{66}$ See eg SATCOM International Group PLC v ORBCOMM International Partners LP $49 \mathrm{~F}$ Supp 2d 331 (SDNY 1999).

67 URS Corporation $v$ The Lebanese Company for the Development and Reconstruction of Beirut 512 F Supp 2d 189 (D Del 2007).

68 ibid 208.

${ }^{69}$ Lac d'amiante du Canada Ltee v Lac d'amiante du Quebec Ltee 1999 Can LII 13500 (QCCA) (injunction ordered to enjoin foreign arbitration).

${ }^{70}$ Compagnie Nationale Air France v Mbaye 2003 Can LII 35834 (QCCA) and Frank Jonkman and Sons Ltd v DGT-Volmatic A/S 2004 Can LII 29287 (ONSC) (injunctions both refused). 
State court an investor would need to show that the courts were acting in collusion with the executive to frustrate the arbitration proceeding or that there was a strong inference of such collusion by reference to the delinquent conduct by the court in relation to the arbitral proceedings. While no evidence of actual collusion between judiciary or executive was found by the ICSID tribunal in Saipem the tribunal nevertheless found the conduct of the Bangladeshi courts to be in breach of the investment treaty.

First, the tribunal had little difficulty in holding that Saipem's right to arbitrate amounted to 'property' which may be capable of expropriation. ${ }^{71}$ Secondly, the acts of the Bangladeshi courts in interfering with the arbitration amounted to 'measures having similar effects' to an expropriation since such acts 'resulted in substantially depriving Saipem of the benefit of the ICC award'. In this regard the tribunal found that Saipem could gain no benefit from the award since Petrobangla had no assets outside Bangladesh and so enforcement in another State 'has no reasonable basis'. ${ }^{72}$

Yet, the tribunal insisted, the mere fact that Saipem suffered a 'substantial deprivation' of its ability to enjoy the benefits of the award is not sufficient for the intervention of the State courts to amount to expropriation. Otherwise, 'any setting aside of an award could then found a claim for expropriation even if ... [it] was ordered by the ... Court upon legitimate grounds'. ${ }^{73}$

This view supports the analysis above that where a court is given power under the arbitration law of the seat to remove an arbitrator or set aside an award a court will not lightly find a breach of international law standards sufficient to found an investment treaty breach. 'Something more' is required and according to the tribunal in Saipem, that is, that the actions of the State court were 'illegal'.

Saipem argued that the court's revocation of the arbitrators' authority was illegal because under the ICC Rules, only the ICC could take such action. The ICSID tribunal however considered that because Dhaka was the seat of arbitration, the Bangladeshi courts had supervisory jurisdiction and so could apply standards under their own law which were not consistent with the ICC Rules. In this regard, the ICSID tribunal was reaffirming the 'seat theory' of international arbitration law whereby parties are bound by the law governing the arbitration which will take precedence over any agreed rules to the contrary. ${ }^{74}$ Such a view contrasts with the rather more controversial 'delocalised' view of international arbitration endorsed by the ICC tribunal in the Salini case above. The approach in Saipem is also consistent with the position advocated above that it will only be in rare cases that State courts will be found in breach of international law standards in supervision of an arbitration. Where, however, a State court makes orders in respect of a foreign arbitration it is implicit in the Saipem award that an ICSID tribunal will be much less deferential to the court.

Saipem's next argument was that the revocation of the tribunal's authority was 'illegal' because on the facts, it was abjectly contrary to universally accepted principles of international arbitration law - an abuse of right and a denial of justice. The ICSID tribunal agreed, noting that the revocation decision was grossly unfair because it was based on a manifestly unfounded finding of misconduct by the ICC arbitrators. ${ }^{75}$ Specifically, the Bangladeshi court 'simply took as granted what Petrobangla falsely

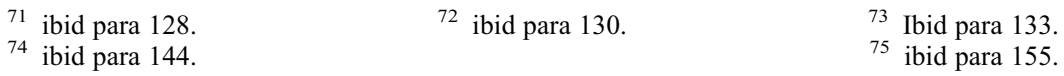


presented ${ }^{76}$ and did not seek or rely upon the testimony of members of the ICC arbitral tribunal. ${ }^{77}$

While the Dhaka court had supervisory jurisdiction over the arbitral process and the competence and 'substantial discretion' to remove the tribunal for misconduct ${ }^{78}$ the court here had exercised its discretion for an end different from that which it was instituted and thus committed an abuse of rights. ${ }^{79}$ Supervision of an arbitration by a State court must be in good faith, in accordance with the rule of law and generally accepted principles of international arbitration. ${ }^{80}$ Furthermore, the action of the court violated article II(1) of the New York Convention which, as noted above, provides that a State court must 'recognise arbitration agreements' ${ }^{81}$ While it was 'generally acknowledged that the issuance of an anti-arbitration injunction' would violate the Convention, so too would an order revoking the authority of the arbitral panel as this also had the effect of preventing or immobilizing the arbitration. ${ }^{82}$ It is interesting to note that the Bangladeshi court had also issued an anti-arbitration injunction in this case which although not referred to by the ICSID tribunal in its reasons may well have influenced its conclusion on this point.

Finally, the tribunal found that in the case of expropriation, there is no duty on the investor to exhaust local remedies in the respondent State ${ }^{83}$ but that even if such a duty applied, Saipem had satisfied it by having 'already litigated the issue of the arbitral misconduct for more than two and a half years in front of different courts in Bangladesh, ${ }^{84}$

\section{CONCLUSION AND EVALUATION}

There is no doubt that Saipem is a significant decision: for the first time, an ICSID tribunal has found the conduct of a State court in relation to an arbitration proceeding within its borders to violate general principles of international arbitration law, and to be in breach of an investment protection treaty. What is particularly significant is that a breach by the State court was found despite the fact that no evidence of direct collusion with the executive was involved. In essence then, the ICSID tribunal indicated a general willingness to review the decisions of State courts in relation to arbitrations taking place within the State's boundaries.

Such an approach is to be commended as it provides investors with a new means of challenging abuses by States in relation to arbitration and one which will also reinforce the system of international arbitration. The tribunal's decision has clear implications not only for future cases involving State arbitration agreements but also arbitrations between exclusively private parties. It will be interesting to see whether future ICSID tribunals adopt a similar analysis in reviewing the orders of a State court in relation to a non-state arbitration or whether they will require an even greater level of delinquency by the court to constitute a breach. In particular, could an investment treaty breach ever be found where a court has purported to apply the provisions of an international instrument such as the New York Convention or the Model Law but done so in an arguably unreasonable manner? If so, then a whole new area of possible challenges

76 ibid para 157.
79 ibid para 161.
82 ibid para 167.
77 ibid para 158.

80 ibid para 186.

83 ibid para 181 .
78 ibid para 159.
81 ibid para 166.
84 ibid para 183. 
may open up for investors which could also reinforce the existing legal infrastructure of international commercial arbitration by demanding closer State adherence to those instruments. Indeed, as discussed above, measures such as anti-arbitration injunctions have already been found by tribunals to be in breach of both international arbitration treaties and customary international law. ${ }^{85}$

Saipem is also interesting because the tribunal effectively applies a 'denial of justice' type test to assess the State court's actions, even though the claim was for expropriation. Such an approach suggests that a common standard will now be applied in determining whether a State court has breached the terms of an investment treaty due to its conduct in relation to an arbitration. This view also has the benefit of limiting the application of the local remedies rule. If, as the tribunal States, investors are not required to exhaust local remedies in claims for expropriation, but are required to do so in claims for denial of justice under a fair and equitable treatment provision, then investors may opt to plead expropriation.

The tribunal in Saipem, therefore, by applying a denial of justice-type standard in the case of expropriation, may have opened up a new avenue for investors to plead denial of justice without having to exhaust local remedies. Such a view is consistent with the general trend in recent ICSID jurisprudence to dispense with the local remedies rule in investor-state arbitration. ${ }^{86}$

What is clear after Saipem, though, is that the realm of investor-state arbitration has now expanded beyond the context of State repudiation of arbitration agreements to embrace a much wider sphere of state conduct in relation to arbitrations. The formerly 'parallel universes' of international commercial arbitration and investor-state arbitration are now coming into closer interaction.

RichARD GARNETT*

${ }^{85}$ See $S G S$ v Pakistan (n 53).

${ }^{86}$ See Helnan International Hotels A/S v Egypt ICSID Case No. ARB/05/19 (Annulment Proceeding) Decision of the Ad Hoc Committee 14 June 2010.

* Professor, Melbourne Law School, University of Melbourne; Consultant, Freehills. Email: r.garnett@unimelb.edu.au 


\section{University Library}

\section{- M M N E R VA A gateway to Melbourne's research publications}

Minerva Access is the Institutional Repository of The University of Melbourne

Author/s:

Garnett, R

Title:

NATIONAL COURT INTERVENTION IN ARBITRATION AS AN INVESTMENT TREATY CLAIM

Date:

2011-04-01

Citation:

Garnett, R. (2011). NATIONAL COURT INTERVENTION IN ARBITRATION AS AN

INVESTMENT TREATY CLAIM. INTERNATIONAL \& COMPARATIVE LAW QUARTERLY, 60

(2), pp.485-498. https://doi.org/10.1017/S0020589311000030.

Publication Status:

Published

Persistent Link:

http://hdl.handle.net/11343/32996 